\title{
Struggling for new narratives in slums and peripheries: complex citizenships amid material and cultural activisms
}

\author{
Lutando por novas narrativas em favelas e periferias: \\ cidadanias complexas em meio a ativismos materiais e culturais
}

Thaisa Cristina Comelli [I]

\begin{abstract}
This article aims to discuss and explore new activisms in slums, focusing on the history, culture, and identity of such territories. We argue that, unlike the traditional urban activism commonly addressed in the literature (which focuses on demands of a material nature), the new activisms seek to add to such struggles a dispute over the narrative about the territory. We explore these manifestations in the light of debates about the conceptual transition of citizenship and intersectional identities. More specifically, we question the existence of a supposed slum-dweller identity in which hegemonic discourses and narratives about the city can be reproduced or subverted and used in the construction of insurgent urban struggles and activisms.
\end{abstract}

Keywords: slum; urban activism; insurgent citizenship; urban identities.

\section{Resumo}

0 presente artigo tem como objetivo debater e explorar os novos ativismos em favelas, cujo foco se posiciona na história, na cultura e na identidade desses territórios. Argumentamos aqui que, diferentemente do tradicional ativismo urbano comumente abordado na literatura (focado em demandas de natureza material), os novos ativismos buscam adicionar, a essas lutas, uma disputa pela narrativa sobre o território. Exploramos essas manifestações à luz de debates sobre a transição conceitual da cidadania e sobre identidades interseccionais. Especialmente, questionamos a existência de uma suposta identidade de favelado na qual os discursos e narrativas hegemônicas sobre a cidade, ora podem ser reproduzidos, ora podem ser subvertidos e utilizados na construção de lutas e ativismos urbanos insurgentes.

Palavras-chave: favela; ativismo urbano; cidadania insurgente; identidades urbanas. 


\section{Introduction}

The epistemological development of favelarelated debates is a path full of traps. On the one hand, the literature still includes descriptions and analyses focused on scarcity and absence; after all, favelas continue to be a locus of urban poverty, social vulnerability and spatial segregation in large cities in Brazil and in the Global South. On the other hand, there are also studies in the literature that seek to focus on the positive aspects of these settlements; the vibrant culture, the creative entrepreneurship, the unwavering resilience of favelas and their dwellers. Therefore, hegemonic narratives on favelas go on as a pendulum between two opposites: the romanticization of urban poverty and the strengthening of negative stereotypes.

Speaking about "the favela" or the "favela dweller" in the singular form is also useless epistemologically. After all, there are countless favelas. Similarly, their histories and peculiarities are numerous. Considering the variety of designs, levels of legal formality, environmental conditions, demography, among other factors, the term favela seems overwhelmingly generic and decontextualized; a sort of invented urban category (Valladares, 2016).

However, the term also bears a certain degree of potential, a thread to connect intersectional struggles. Amid so many generalizations and stereotypes, which are the possible counter-narratives on the diversity of favelas? What are the relations between these narratives, the city and the complex identities which inhabit it? If these narratives are nonhegemonic or insurgent, to what extent can they catalyze transformation in the city's territories? Can the production of counternarratives be considered, in itself, a type of urban activism?

The present paper departs from the above inquiries. It seeks to draw a critical reflection on new activisms occurring in favelas and peripheral settlements in Brazil. More specifically, the analysis seeks to explore what here is called material activism and cultural urban activism. From such insurgent planning spaces, the category of favela is widely contested, as well as its attached stereotypes and narratives.

The analysis is split into two different stages: one that seeks to discuss citizenship and the complexity of "favela" and "peripheral" identities in the transition from modernity to post-modernity; and another one particularly focused on broadly exploring different types of urban activism from Rio de Janeiro's experience. The overall goal is to expand knowledge in the fields of insurgency and activism in spaces of social vulnerability. The paper adds to the traditional demands on land, housing and infrastructure, new and creative repertoires that discuss the urban space through the themes of education, culture and history.

\section{Citizenships and complex identities}

\section{From universal to insurgent}

When analyzing the evolution of the concept of citizenship throughout the $19^{\text {th }}$ and $20^{\text {th }}$ centuries, British sociologist Thomas Marshall 
(1967) suggested that three elements helped to understand its trajectory in western societies: the civil, the political and the social. In the civil realm, since the $19^{\text {th }}$ century, citizenship was intimately linked to individual freedom and to modern ideals of Liberal Democracy. In the $20^{\text {th }}$ century, with the assurance of universal suffrage in many countries, citizenship is then also associated to the political right to participate. Also in the $20^{\text {th }}$ century, citizenship acquires social nuances. In other words, on top of universal rights, citizenship starts to aggregate ideas around dignity, wellbeing, and development. This is the case of the right to quality basic education and the right to accessible healthcare.

Marshall's main argument is that citizenship is a status acquired by individuals. It has to do with individual and universal rights and liberties, which ultimately contrasts with the historical development of social classes. In other words, "citizenship" and "social class" are incompatible ideas; while modern citizenship has been established on the basis of equality, social class is, in essence, a system of inequality (ibid.). It is this intrinsic limitation of citizenship in contemporary capitalist societies which renders to certain individuals or groups the status of "second-class citizen" or "sub-citizen" (Kowarick, 1991).

With the advent of the urban phenomenon, the limitations of universal citizenship also start to materialize in large cities and its spaces. In this context, the status of informality and subalternity of many settlements is automatically transferred to their dwellers (Roy, 2011), creating a sort of urban class division. In countries like Brazil, the terms "suburban", "peripheral" or "favela dweller" mean more than geographical relations between individuals and the city; they are also symbolically charged with the notion of marginality, which is thus connected to the social status of certain individuals and groups (Perlman, 1977).

In this context of deep inequalities, throughout the $20^{\text {th }}$ century, the term "Right to the City" became an instrument for citizenship struggles and for justice-related claims which dialogue with urban spaces. After all, if cities are built by multiple hands, the use and access to it should be a collective right, not an individual privilege (Lefebvre, 2001). More recently, these debates acquired new nuances, operating as flags for effective participation in urban politics. New interpretations highlight that the Right to the City is more than a right to access goods and services. It is a right to decide on urban trajectories, to participate in the production and use of space, to make choices, to deliberate, to contest and transform inequalities and other types of injustice (Harvey, 2014).

In Brazil, debates that relate citizenship and the urban phenomenon are not recent. In the 1970s, for instance, authors such as James Holston and Janice Perlman were dedicated to studying autoconstructed settlements in cities such as Rio de Janeiro and São Paulo. They sought to understand stigmas, myths and strategies for contested citizenship which were attached to marginalized territories and their builders (Perlman, 1977; Holston, 2013). In the classic Insurgent citizenship, Holston explores the differentiated forms of citizenship in the country. He analyzed not only how the State legalizes and legitimizes social differences, but also how peripheral and favela dwellers recognize themselves as the producers and consumers of urban life. Insurgent citizens 
then start to demand from the state the same rights recognized for entrenched citizens, that is, those historically privileged by the Brazilian legalnormative apparatus (Holston, 2013, p. 22).

Other particularities in Holston's studies are relevant to this analysis. The first one is the understanding of the urban not only as a background for citizen struggles, but as a protagonist category in itself. That is, citizens fight for the urban, not only at/in the urban. Moreover, the author observes that, although insurgent and corrosive, periphery and favela dwellers' struggle for the citizenship is not part of an attempt to revolutionize the system that produces of socio-spatial inequalities. They are not - or at least they were not an anti-capitalist struggle in essence. This means that insurgent citizens operate under the same paradigms of entrenched citizens, claiming rights such as private property, land-related rights, and the individual-based legalization of settlements. Despite that, the author considers that such struggles are still insurgent because,

rather than merely nourish new versions of the hegemonic, the insurgent disrupts: it remains conjoined with the entrenched, but in an unbalanced and corrosive entanglement that unsettles both state and society. (Ibid., p. 35)

Afterwards, the concept of insurgency was also addressed directly in the field of urban planning theory. Scholars approached the role of Global South civil society and its peripheral urbanists amid the development and dispute of urban territories. Critical debates based on radical democracy theory and post-colonial theory (among other postmodern and post-positivist lines of thought) focused on exploring forms of planning based on conflict, dissent, and the strengthening of urban southern knowledge (Miraftab, 2004; Watson, 2013; Caldeira, 2017).

Based on this Southern insurgent perspective, Miraftab explores manifestations of activism in which citizens take the cities' spaces in their own "hands" (Miraftab, 2004, $2009,2020)$. She draws on the concepts of "invited" and "invented" spaces to differentiate arenas of urban activism and citizen participation with greater or lesser degree of legitimacy from the status quo. Miraftab reinforces that both spaces are democratic, coproduced and frequently occupied by insurgent activists. However, she observes the insufficiency of invited spaces in contrast with the transformative character of invented spaces. Recalling the work of Svirsky (2010), she argues that "the activism that seeks only to assure the mechanisms of representative democracy is a 'slave activism'" (Svirsky, 2010, apud Miraftab, 2016). Miraftab advocates that insurgent urban planning must be capable of corroding the very pillars that support the field in order to build a more human form of urbanism (Miraftab, 2016).

However, it should be pointed out that debates on urban citizenship increasingly relate to complex territorial scales. Drawing on these challenges, ideas about the political common, the urban commons and the epistemologies of the South are among those which seek to overcome the traditional borders of modernity, often limited to NationStates. They aim to reconstruct themes related to rights and citizenship based on a global collectivity (Dardot and Laval, 2017; Harvey, 2014; Sousa Santos, 2019). In other words, 
these theoretical lines of inquiry advocate that socio-spatial problems produced in a global scale should be debated and overcome in an inter-scale, democratic and equally global manner. Such rationale also applies to the Right to the City banner and the multiple antidomination urban struggles that overlap and dialogue for that right (Harvey, 2014).

In the case of peripheries, favelas and other Southern territories marked by autoconstruction, marginalization, and insurgent citizenship (Caldeira, 2017), one should note that there are many common challenges of both local and global character to be tackled collectively. After all, these settlements house a large part of the global population; and they are still growing fast, often occupying more land than they grow in population, besides verticalizing in a dense and unhealthy manner (UN-Habitat, 2020).

But beyond material and morphological questions, or beyond the traditional urban narratives based on shortage and absence, there are other symbolic and identityrelated issues that connect individuals and urban collectives around common projects for favelas and southern peripheries. This paper argues that, by reproducing, mixing elements, reframing and subverting stigmas and stereotypes, the "new" insurgent citizens of favelas and peripheries engage with the hegemonic in an urban struggle with a strong cultural, pedagogical and identity character: a struggle for new narratives. In the following section, the paper will briefly explore the complex and intersectional character of the favela identity and its narratives.

\section{The favela as a complex urban identity}

None of us exist in isolation. Our sense of identity is deeply linked to the world, to the environment, to the society and to other beings that surround us (Mead, 1934). Just like the transition from modernity to postmodernity brought about the fragmentation of the single discourse and a hegemonic worldview (Sousa Santos, 2002), it also led to fragmented "cultural landscapes" related to class, gender, sexuality, ethnicity and nationality, which were previously assured by modern discourse (Hall and Du Gay, 1996, p. 275). The notion of "self" and its link to time and space are now more fluid and volatile, making it difficult for us to locate ourselves as coherent social individuals and citizens.

This modern identity crisis, however, is nothing but a mirage. There never was a static, cohesive and complete individual or collective identity (ibid.), especially if such identity is analyzed longitudinally. Just like the idea of citizenship was once intimately linked to the notion of the nation-State and now tends to expands to an array of social sectors and territorial scales, cultural identities are also undergoing a moment of expansion and collective resignification.

In this context, analyses that link city and identity should also be capable of operating fluidly. Mostly because, in practice, bodies and causes move freely through the urban space. Hence, it does not make sense to describe and analyze city dwellers merely based on where they were born or where they live; we are all continuously developing bonds and identity 
relations with different city spaces. Also, in a globalized world, we are often building bonds with different cities and territories simultaneously. We may even build identity relations that move beyond physical city spaces; that is, bonds with immaterial causes and interests.

Drawing on this rationale, we note the difficulty to approach an assumed identity of favela, suburb and peripheral residents for the production of insurgent urban struggles. In some cases, such category may work as a reinforcement of stereotypes produced by hegemonic perspectives on the city. In others, this identity may be able to translate and connect the plurality of urban bodies and demands; it may serve as a common thread for citizen counter-hegemonic narratives. The peripheral/favela identity is somewhat a tension that both reduces and connects: connects complex identities that fight for the Right to the City, while also compacting and reducing them to a specific type of territory.

Amid such "identity complexity", certain aspects and demands tend to gain centrality in current political-urban debates. In the movements studied in Insurgent Citizenship (Holston, 2013), classbased struggles are highlighted and used as a thread to connect citizenship-driven peripheral struggles. In other southern peripheral and favela movements, there is also a growing emphasis in gender, race, religion and ethnicity (Doshi, 2012). Racial issues, particularly, have a strong connection to the history of urbanization in Brazil. There, more than $70 \%$ of the poorest in the country are black. And according to racial maps, ${ }^{1}$ black and brown individuals are the majority in large cities' peripheries and slums, while white folks dwell in the central, safer, more ventilated neighborhoods with the best services.

Moreover, symbolic and affective elements connect favela citizens beyond class, race or gender. According to Jovchelovitch and Priego-Hernandez (2013), although favela dwellers' identity is strongly linked to social class, three other discourses/narratives emerge when individuals describe their place of residence: the sense of belonging (an emotional attachment to the physical space), an attempt to reject fears associated to space, and the perception of social cohesion (linked to solidarity and communities' social capital). In other words, the identity link of favela dwellers to their place of residence often extrapolates corporeal or material dimensions. Affective and symbolic nuances also appear. Thus, we note that identity is a fluid and relational notion, with bonds that are configurated at different times and scales.

Guareschi et al. (2002), on the other hand, observed among young favela dwellers an almost indistinguishable mix of ideas about race and class, the latter dimension being the dominant explanation about their current reality. Also, experiences on discrimination are constantly linked to diffuse notions about citizenship, in which leaving the favela is the only way of acquiring rights and "becoming someone". For some of the interviewees, it is the territory of the favela itself together with their identities of class and race that make it impossible to acquire full citizenship (ibid.).

In the many resistance to evictions experiences and also in land and housing rights struggles in favelas, it is possible to observe how race, gender and culture appear diffusely, even thou they are determinant 
in the development of intersectional and complex political identities. Such identities are constantly rearticulating in time and space, depending on collectivities' members, leaders and demands, which renders a plurality of urban "cultural landscapes" (Keisha-Khan, 2004; Alves, 2012).

Finally, one should note the role of various types of cultural manifestations associated with (or produced by) favelas, peripheries and their dwellers. Such manifestations often operate as instruments or catalyzers of intersectional identities and urban struggles (Guasco, 2001; Patrocínio, 2013). Although these are not necessarily connected to social movements and urban activisms, they contribute to the development of subaltern/peripheral identities that claim equality of rights or appropriate their own stereotypes to build criticisms based on difference and diversity.

"What if I don't resist and leave? Give him everything then, what will it be? [...] The beauty of a people The favela does not succumb My African side emerges, redeems me The evil angel entices the little boy Every night someone dies Black or poor around here" (Criolo, 2014)

"I'm a woman, I'm black, my hair is thick Strong, authoritarian and sometimes fragile, I assume My fragility does not diminish my strength [...] I am a fearless woman, my attitude comes from the ghetto". (MC Carol, 2016)

In the two excerpts above, the artists criticize the oppression of the favela citizen by different oppression systems. Simultaneously, such oppression is juxtaposed to the strength, the vitality and the beauty of complex identities and their territories of origin. Both songs are peripheral/favelarelated narratives with a strong political and cultural content. They make evident favelas' complex identities. But they also make evident certain political threads composed of global geographies and marginalized urban territories: Africa, favela, ghetto.

Overall, the panorama outlined in this section seeks to highlight different shades of discourse that shape contemporary favela and peripheral identities. The idea of "favela as a complex identity" means, therefore, that there are different emphases and nuances (of class, race, gender, space) that can emerge in cultural and political manifestations and in the discourse of favela residents according to the context in question. Often, especially in the case of current urban activisms, the favela identity has been used both as product and as a producer of culture and politics. That is, it is a complex identity that operates through the subversion stereotypes and as a banner for insurgent urban struggles. Thus, instead of reducing the favela resident to the favela, contemporary urban activism uses the favela category flag as an entry point and guideline to build demands and narratives.

\section{Favela and peripheral activism}

In the context of this paper, the term "activism" refers to participatory arenas or counter-hegemonic actions that contest or claim something for a greater collectivity. In the following paragraphs, we will address formats of activism that dialogue with the theme of insurgent citizenship and with the autoconstructed settlements in the Global South, particularly peripheries and favelas. Such reflections are based on continuous 
participatory observation work and on an ongoing collaboration with various urban collectives and social projects in the favelas of the South, North and West Zones in Rio de Janeiro.

As to the analytical structure of the text, the discussion is split into two main axes, which here are understood as common threads that connect Global South favelas complex identities and struggles. The first guiding thread is the material, which corresponds to struggles for land and housing. These are the "traditional" activisms that emerged from different autoconstructed settlements throughout the $20^{\text {th }}$ century, often after displacement threats. Besides such important material link, we argue that there is also an immaterial link emerging in more recent decades. Here, the second thread is characterized by an emphasis in issues of identity, in the individual history of each autoconstructed settlement and in artistic, pedagogical and cultural manifestations. We argue that this type of "urban cultural activism" represents a series of struggles for new narratives about favelas. Although it is possible to suggest that material struggles are older and immaterial struggles are more recent, it should be highlighted that both are currently juxtaposed and intimately connected in favela and peripheral territories. In other words, even though they appear segregated in this paper, in practice they are not easily dissociated.
Fighting for land, housing and infrastructure: material activism

The origins of activism in favelas has not been dated accurately, probably because it is mixed with the very nature and emergence of these settlements. Since favelas were identified as strong urban phenomenon, public policies moved between initiatives of removal, cooptation, assistance and, as is most observed today, urbanization projects with a focus on housing, infrastructure and qualification or creation of public spaces. Therefore, both in opposition to state hygienist actions or with the goal of promoting better living conditions for dwellers, activism in the form of collective anti-removal actions or community efforts to build infrastructure and public spaces were part of the history of countless favelas in the country. This often emphasized the assumed cohesiveness credited to these spaces and their dwellers (Gonçalves, 2013).

During the first half of the $20^{\text {th }}$ century, evictions were the state's common action paradigm, which was in turn legitimized by the narrative of the "favela as a problem" (Burgos, 1998, p. 34) and by the social construction of the favelado's identity as a vagabond, criminal or incapable. As to their citizenship status, Santos (1979) recalls that, around the 1930s, the situation in Brazil was one of a "regulated citizenship". This means that people with no occupations (formal jobs or employment bonds) were identified and characterized as pre-citizens 
by the Brazilian legal apparatus. As to political participation, one should note that the former Constitution did not allow illiterate people to vote, which, at the time, included a substantial part of favela dwellers (Burgos, 1998).

At the time, neither citizenship or civil and political rights were massively contested in favelas; nor the favela identity was commonly used as a flag for broader political struggles. However, the pursuit of better living conditions in these settlements and their very condition of socio-spatial vulnerability were, little by little, being crystallized in the form of Dwellers' Associations. In those groups, political leaderships, whether democratically chosen or not, advocated for the interests of all favela dwellers. In Rio de Janeiro, the Special Service for the Recovery of Slums and Unhygienic Housing (Serfha), active in the early 1960s, stimulated the creation of several dwellers' associations in favelas where they did not yet exist, in order to facilitate dialogue of the population with the state. The communication between leaderships and activists from different favelas culminated in the creation, in 1963, of the Federation of Favela Associations of the State of Guanabara (Fafeg/Faferj), one of the greatest national favela representations to the present day (Gonçalves, 2013).

Also, at the time, planners such as Carlos Nelson F. dos Santos emerged as pioneers in participatory processes in favelas. In those experiences, planners cease to be protagonists/leaders to become the facilitators of local interests. Drawing on emblematic experiences such as that of the Brás de Pina favela in the 1960s (Santos, 1981), he civilizing pedagogy of Brazilian modernism was, little by little, being challenged and replaced by a stimulus of local knowledge and capabilities.
In this new paradigm, dwellers and activists themselves were the protagonists, not architects and urban planners. Nevertheless, one should note that traditional patronage and paternalistic patterns (and quid-pro-quo practices) never thoroughly disappeared (Gonçalves, 2013).

At the second half of the 1960s and during the 1970s, the military dictatorship led to a weakened activism landscape in favelas (Valladares, 2000). While some political leaders were persecuted, others were co-opted. A few associations survived, claiming they were apolitical and exclusively technical. In some cases, dwellers' associations even collaborated with the state in the context of mass evictions and/or settlements relocations. Some of these complex alliances/conflicts between local activists and the state (and other hegemonic powers) are described by Perlman (1977) in the context of her ethnographic work at Morro da Catacumba in the 70's.

In the 1980s, with the partial reopening of the military regime, more conflictive and counter-hegemonic forms of activism started to reorganize again in favelas. The active participation of favela associations in spaces such as the National Movement for Urban Reform (MNRU) also played an important role in a national context of re-democratization. Moreover, it should be noted that the MNRU was one of the cornerstones in the production of urban-focused normative instruments still in force today. It is the case of the City Statute, promulgated in 2001 (Maricato, 2017).

As suggested before, despite the importance of dwellers associations for urban activism in favelas, the role of these organizations has changed and become more complex over time. Particularly in the case of 
Rio de Janeiro, associations play an ambivalent role concerning the city's power structures; at times they act insurgently and counterhegemonically (e.g. in alliance with antievictions or other rights-based movements); at other times, they form opaque alliances with the state and with parallel powers (drug cartels or militias). But beyond the "official" dwellers associations, there is currently a constellation of political groups with internal ideological and identity differences and dissidences. Such diverse landscape ends up shaping specific political profiles of the different favelas in the city. In sum, although traditional land, housing and urban infrastructure struggles contributed to the formation of many favela dwellers associations in the $20^{\text {th }}$ century, not all favela associations or collectives are necessarily an insurgent form of activism (Burgos, 1998).

In the midst of this complexity of political alliances and worldviews, the fact is that a sequence of historical struggles of material nature contributed to a paradigm shift regarding the action of the state in autoconstructed settlements (Conde, 2004). Re-democratization leveraged the process, although the former displacement paradigm never vanished entirely. Even today, there are still notorious cases such as that of Vila Autódromo, which brought about experiences of conflict planning in a context of urban disputes related to megaevents (Vainer et al., 2013).

Despite still relevant, cases of forced and massive displacement are no longer dominant in Brazil. From the 1990s onwards, especially after the Favela Bairro program, the idea of integrating the favela into the city - which includes a discourse focused on citizenship and rights - became the norm in terms of state action. Today, the tonic of most contemporary slum upgrading programs is one of spatial integration and citizen participation. Moreover, the previously local experiences of favela urbanization acquired national importance. In Brazil, there is the paradigmatic Growth Acceleration Program (PAC), which not only poured billions into slum upgrading, but also institutionalized invited spaces of participation based on the legal obligation of "social work" (Cardoso and Denaldi, 2018). In the case of Rio de Janeiro, the social work became a "social upgrading site" (Canteiro Social in Portuguese), a physical space for dialogue, guidance and negotiation around issues of infrastructure, housing, mobility, and other urban-related themes (Comelli and Silva, 2018).

Initiatives such as PAC's Social Upgrading Site in Rio de Janeiro illustrate the concept of "invited planning spaces" (Miraftab, 2004), in which citizen participation is legitimized by the State and the status quo. But despite being relevant from the standpoint of democratizing the production of urban space, invited spaces in such territories proved to be insufficient for the effective incorporation of residents' demands into urban planning. On the other hand, the existence of large urban projects with "invited" arenas of participation contributed to catalyze preexisting insurgent movements and activisms, which articulate themselves around such projects to produce "invented planning spaces" and concrete material demands (Miraftab, 2020).

An example of this dynamic of coconstitution which connects invited and invented planning spaces in favelas is the case of the cable car project as part of PAC 2 in Rocinha. While in the invited spaces of the Social Upgrading Site, the stated pushed for the construction of a cable car in the 
community using a discourse of mobility; in insurgent, invented spaces, favela citizens and support groups used basic sanitation as a counter-hegemonic discourse. The "Telefante" (Telefante, a mix of the terms "teleférico" cable car - and white elephant) campaign said: Basic sanitation, yes; white elephant, no. In the case of Rocinha, sanitation was a material thread for urban activism in the context of PAC.

Although material activism remains relevant as a guiding thread for urban struggles, research on insurgency should note new phenomena that begin to affect favelas and peripheries, triggering "new" types of activism. In Rio de Janeiro's South Zone favelas, for instance, a conjuncture of factors and policies ended up contributing, around the 2000s, to a growth of tourism in these settlements, in addition to the increase in sales and rent property values (Comelli, Anguelovski and Chu, 2018). In fact, tourism in favelas is not a recent phenomenon (Frenzel, Koens and Steinbrink, 2012), but urbanization policies, land regularization and pacification open a path so entrepreneurs, foreigners and the middle/high class could settle in these spaces (Comelli, Anguelovski and Chu, 2018).

Amid ambivalent and conflicting perceptions concerning these new actors and urban dynamics (ibid.), favela dwellers and activists naturally began reacting to the new reality. Opposing more invasive tourism models, such as the "safari tourism", local activists and dwellers in various favelas

Image 1 - Illustration created for the campaign against the cable car

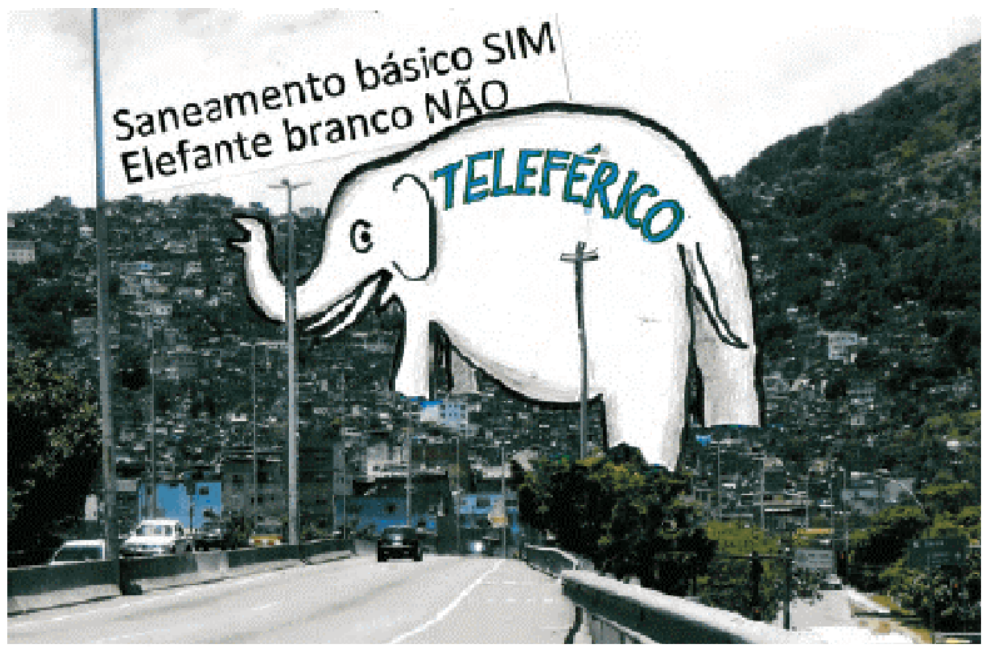

Source: Rocinha without Borders urban collective. 
and peripheral areas started organizing to promote "community-based tourism" (Fagerlande, 2018), which is focused on the production of local narratives with strong political (insurgent) notes.

The case of community-based tourism illustrates how contemporary city phenomena catalyze other forms of immaterial peripheral activism, that is, an activism focused on the knowledge, history and alternative narratives about marginalized territories. This paper argues that, although such initiatives are not usually classified as social movements or urban struggles per se, they produce a form of activism with transformative potential. Mainly because they seek to show the potency of favelas and the complexity of its dwellers' histories and identities.

\section{Fighting for new narratives: urban cultural activism}

In recent decades, a mixture of investments and urban, economic and security policies has stimulated a supposed "opening" of slums to the world (and to global capital). The apex of this process, at least in Rio de Janeiro, was the period immediately prior to the megaevents (Comelli, Anguelovski and Chu, 2018). The definitive turn of Brazilian cities towards neoliberal governance standards also affected many favelas. Little by little, in pacified or close to tourist attraction favelas, new hostels, hotels, art galleries and restaurants aiming at middle, high classes and the foreign public started being quite common in the urban landscape (Fagerlande, 2018). This resulted in higher prices and changes in the cultural and social dynamics of older residents.
Nevertheless, the access to new political and economic opportunities also opened a path for insurgent actions with a focus on the urban space. It is the case of the forms of activism mentioned in this paper. This ongoing ethnography, which began in the year of the Brazilian World Cup (2014), analyses movements, companies, collectives and associations focused on promoting new narratives about the favelas. The participant observation of favela museums, communitybased tourism groups, environmental associations and independent media included visits to events, lectures and dialogue spaces, as well as the follow up of these groups in social media.

The table below illustrates a few of initiatives followed over the past seven years. Here, we argue that these initiates are invented spaces of urban cultural activism. Some are not necessarily new. For instance, we included the community radio of the favelas Cantagalo/Pavão-Pavãozinho which, according to local activists, is the first community (favela-led) radio in the city, founded in the 1990s. However, the installations had little maintenance throughout the decades and the initiative had to stop for several years. It could only be reactivated in 2018 due to private donations or fundraising events. Other initiatives such as the Favela News Agency (ANF) started as small independent media (2001), only to become an NGO afterwards, in 2005. In short, the point is that the accumulation of these cultural initiatives is relatively recent.

Each organization has its own history. Each emerged from a conjuncture of community mobilizations and partnerships with sectors of civil society and institutions, 
Table 1 - A few spaces and groups of activisms monitored for the purpose of this paper

\begin{tabular}{|c|c|c|c|}
\hline Headquarters & Group & $\begin{array}{c}\text { Year of foundation / } \\
\text { inauguration }\end{array}$ & $\begin{array}{l}\text { Main field } \\
\text { of operation }\end{array}$ \\
\hline Favela do Horto & Horto Florestal Museum & Not available I & $\begin{array}{c}\text { History / } \\
\text { Environmental } \\
\text { preservation }\end{array}$ \\
\hline Complexo da Maré & Maré Museum & 2006 & History \\
\hline Vila Autódromo & Evictions Museum & 2016 & History \\
\hline $\begin{array}{l}\text { Favelas Cantagalo / } \\
\text { Pavão-pavãozinho }\end{array}$ & $\begin{array}{l}\text { Favela Museum } \\
\text { (MUF) }\end{array}$ & 2008 & History \\
\hline $\begin{array}{l}\text { Favelas Babilônia / } \\
\text { Chapéu mangueira }\end{array}$ & CoopBabilônia & 1997 / 2006 & $\begin{array}{l}\text { Environmental } \\
\text { preservationl }\end{array}$ \\
\hline $\mathrm{N} / \mathrm{a}$ & Favela News Agency & $2001 / 2005$ & Communication \\
\hline Favela da Rocinha & Favela Roça Newspaper & 2012 & Communication \\
\hline Favela da Rocinha & Sankofa Museum & 2008 & History \\
\hline Complexo do Alemão & $\begin{array}{l}\text { Voice of Communities } \\
\text { Newspaper }\end{array}$ & 2005 & Communication \\
\hline Cantagalo /Pavão-pavãozinho & $\begin{array}{l}\text { Cantagalo Community } \\
\text { Radio }\end{array}$ & 2018 & Communication \\
\hline
\end{tabular}

Obs: the dates of foundation are not accurate and could vary slightly, since many of these spaces consolidated gradually and, in a few cases, were active only for a small period of time.

such as universities and other city-wide activism groups. There is, for instance, the case of the Sankofa Museum in Rocinha, which emerged from different cultural events and fora in the favela. There is also the case of the Evictions Museum at Vila Autódromo, which emerged from a conflictive planning experience against the threat of evictions (Vainer et al., 2013). In both cases, however, there is a common intention to preserve the memory and the history of favelas. The material struggle thread is still central for these cultural and pedagogical activisms, but the repertoire of insurgent spaces is different: it consists in producing new narratives about favela and peripheral territories.
The content of each narrative and action repertoire also varies depending on the particular context of these cultural activism spaces, their thematic focuses and collective objectives. In the case of the Horto Florestal Museum, for example, there is an environmental and sustainability tonic that mixes with the fight against evictions. In the case of the Sankofa Museum, the history of the favela is told through a walk in the urban space itself, in which it is possible to observe different architectural typologies, key streets and aleys; that is, the museum is in the open and the story is told from a path carefully selected by activists, in which urban narratives are mixed with political narratives; that is, 
the museum is the favela as a whole, and the story is told from a path carefully selected by activists, in which urban narratives mix with political narratives. In the case of the Evictions Museum, as the name implies, the keynote is the history of removal/displacement policies which marked the city and its most vulnerable inhabitants.

The temporality of the emergence of favela museums also deserves attention; it evidences a strengthening of traditional activism, which is added to a continuous learning about the urban space and its history. Such knowledge starts to be transmitted to the rest of the population from the very gap left by this moment of "opening" of favelas. Moreover, the paper highlights the key role of favela museums in the building of active and insurgent forms of citizenship, which may operate in local, national and global scales. A form of citizenship in which the record of struggles and of the mere existence of favelas is a constant reminder of the Right to the City.

The resistance was very important for us to be able to stay in that community. [...] The favela is ours, it is our right, because it is part of the city, and that is not new. [...] What we have left is our right to stay there. So when we talk about upgrading the favela, we are talking about giving people the right to their land, to their history. It is not just about your home, it is our history. We build our homes to live in them, not to be displaced. We are not animals to be moved away. We need to be aware of that, of the right to the territory. (Leader of Vila Autódromo speech, 2018)

In this context, it is also worth remembering the important role of favela museums as a bridge and connection between the different city inhabitants. Currently, many of these museums and their activists are also engaged with community-based tourism, which helps to open communication channels with a not so engaged sector of the urban population. In this case, activists share a commitment to raise awareness about such counter-narratives in those outside of the reality of favelas.

The tourists that come are impressed with the organization we have here. The favelas in Rio de Janeiro have been shown in the media as violent places for a long time. [...] Babilônia cannot be seen as a ghetto, an area simply dominated by a drug faction or another. It has to be understood as a public space in itself, where people go up and visit, where they understand more about the daily lives of the people who live here, where they interact with them [...]. (Member of CoopBabilonia during semistructured interview, 2015)

With regard to identity issues, in many cases, activists who work with communitybased tourism also see themselves as members of an urban resistance, that is, in direct opposition to the official and parallel powers that operate in the favelas: the State at different levels, drug factions and militias.

\footnotetext{
Here we dwell violence. [...] The fact that we continue working in the midst of everything that is been going on [violence and military intervention] is already a form of resistance. (Activist from the Sankofa Museum in Rocinha during a dialogue space, 2018)
}

Finally, independent and communitybased media should also be highlighted. Such initiatives play a key role by reporting and 
denouncing events within a certain favela, events that connect favelas, and events in the rest of the city which affect favelas. Besides the news pieces which, similarly to the museums narratives, are told from the perspective of favela dwellers, community newspapers and radios often report on state actions. This ultimately opens a path for more conflictive and insurgent forms of citizen participation. Mostly because their discourse on the city is often less coopted by hegemonic urban narratives. As an illustration, in the excerpt below, an activist who collaborates with the Favela News Agency reflects on the favela dweller's identity and social condition. He highlights the building of an individual selfesteem, which relates to a bond with one's place of origin.

The birth of a 'favelado' occurs when he manages to project, inside and outside himself, a feeling of belonging to his community. The favelado is born when he can see that piece of land, politically and socially excluded, as his point of origin. The favelado comes to life when the favela becomes his starting point for thinking and exploring the world, both in the geographical sphere and in his positioning and critical sense towards society and its ills. Believe me: this can take time to happen. (Dweller of Jacarezinho and ANF $^{2}$ collaborator, 2017)

This activist's discourse translates well the central argument of this paper: the struggle for new narratives is a new guiding thread of urban activism that connects favela dwellers' complex identities and that contributes to the production of insurgent planning spaces. The traditional thread of material activism, added to a feeling of belonging and to the construction of a nuanced identity, contributes to the production of counter-narratives and new citizenship demands. Although material struggles remain important for favela dwellers, given that they refer to basic needs and rights, struggles for new narratives show these citizens' capacity to subvert a negative stereotype and turn it into a flag for all kinds of struggle. The complex favela identity, when properly politicized, may be the starting point for a critical view of the city. In this sense, urban cultural activism has an insurgent and transformative potential precisely because of its capacity to erode the foundations of stigma and marginality.

\section{Final thoughts}

This paper sought to connect the themes of citizenship, cultural identity and urban activism in the context of favelas and peripheries. The main objective here was to explore a continuous repertoire of insurgent actions and spaces, which have acquired new nuances over time. The main argument is that, although more subtle, slow and diffuse, strategies of activism linked to the history and culture of favelas may be as transformative as the traditional struggles for land, housing and infrastructure in the long term.

In these final reflections, we also recall and develop important points which relate to the debates stated in this paper. The first point regards the need to understand insurgent citizenship beyond mere class conflict. The understanding of the favela or peripheral dweller as an oppressed or subaltern individual, although fundamental for the understanding of segregation and socio- 
spatial dynamics, is no longer sufficient for a contemporary reading of urban activisms. Class conflict still exists, and capitalist production of space still severely affects sociospatial dynamics. However, to the class layer, it is essential to add other social identities such as age, gender, sexuality, race, among others.

A favela identity cannot not exist as a static and perennial category. The identities of favela residents, as well as every other city resident, are fluid and migrate over time between causes and spaces. This broad and flexible understanding of the notion of identity according to time/space/cause (beyond the individual) is a basic premise for the construction of critical urban theory related to peripheral territories and towards postmodernity. The favela resident is and is not a favelado/a, simultaneously. They are universal citizens insofar as they seeks to equate rights and insofar as they perceive themselves as deservers of land, housing and infrastructure due to their condition of producers and consumers of the urban. But they are also favela-bred, insofar as they perceive their relationship with the urban as a reason for pride and for the subversion of a hegemonic discourse. In sum, they are peripheral in their own terms and, for this reason, they are able to produce new and legitimate narratives about their territories of origin and dwelling.

\section{https://orcid.org/0000-0003-3173-2602}

Federal University of Rio de Janeiro, Architecture and Urbanism School, Graduate Program in Urbanism. Rio de Janeiro, RJ/Brazil.

thaisacomelli@ufrj.br

Translation: this article was translated from Portuguese to English by Cristiano Botafogo and further reviewed by the author.

\section{Acknowledgements}

This work was carried out with the support of the Coordination for the Improvement of Higher Education Personnel (CAPES), Financing Code 001. The ongoing research also has the support of the National Council for Scientific and Technological Development (CNPq), process $141281 / 2017-0$. 


\section{Notes}

(1) Available at: <https://www.cidadessustentaveis.org.br/arquivos/mapa_desigualdade_2018_ apresentacao.pdf>. Accessed: December 28, 2020.

(2) Excerpt extracted from a piece at the Favelas News Agency website. Available at: https://www. anf.org.br/quando-nasce-um-favelado/ (in Portuguese). Accessed: January 5, 2019.

\section{References}

ALVES, J. A. (2012). Dialectics of the African Diaspora: the glocality of race and resistance in the Brazilian economy of violence. Cultural Dynamics, v. 24, n. 1, pp. 31-57.

BURGOS, M. B. (1998). “Dos parques proletários ao Favela-Bairro: as políticas públicas nas favelas do Rio de Janeiro". In: ZALUAR, A; ALVITO, M (orgs.). Um século de favela. Rio de Janeiro, Ed. FGV.

CALDEIRA, T. (2017). Peripheral urbanization: Autoconstruction, transversal logics, and politics in cities of the global south. Environment and Planning D: Society and Space, v. 35, n. 1, pp. 3-20.

CARDOSO, A. L.; DENALDI, R. (2018). Urbanização de favelas no Brasil: um balanço preliminar do PAC. Rio de Janeiro, Letra Capital.

COMELLI, T; ANGUELOVSKI, I; CHU, E. (2018). Socio-spatial legibility, discipline, and gentrification through favela upgrading in Rio de Janeiro. City, v. 22, n. 5-6, pp. 1-24.

COMELLI, T; SILVA, R. (2018). Participação nas favelas cariocas contemporâneas: uma reflexão à luz dos conceitos de emancipação e deliberação. In: III SEMINÁRIO NACIONAL SOBRE URBANIZAÇÃO DE FAVELAS. Anais... Salvador, UCSAL.

CONDE, L. (2004). Favela-Bairro, uma outra história da cidade do Rio de Janeiro: 1993/2000 uma ação urbanizadora para o Rio de Janeiro. Rio de Janeiro, ViverCidades.

DARDOT, P; LAVAL, C. (2017). Comum: ensaio sobre a revolução no século XXI. São Paulo, Boitempo.

DOSHI, S. (2012). "The politics of persuasion: gendered slum citizenship in neoliberal Mumbai”. In: DESAI, R.; SANYAL, R. (orgs.). Urbanizing citizenship: contested spaces in Indian cities. Nova Delhi, Sage.

FAGERLANDE, S. M. R. (2018). Grandes eventos esportivos: impactos nas favelas do Rio de Janeiro. Bitácora Urbano Territorial, v. 28, n. 2, pp. 143-151.

FRENZEL, F; KOENS, K; STEINBRINK, M. (orgs.) (2012). Slum tourism: poverty, power and ethics. Londres/Nova York, Routledge.

GONÇALVES, R. (2013). Favelas do Rio de Janeiro: história e direito. Rio de Janeiro, PUC-Rio.

GUARESCHI, N. et al. (2002). As relações raciais na construção das identidades. Psicologia em estudo, v. 7, n. 2, pp. 55-64. 
GUASCO, P. P M. (2001). Num país chamado Periferia: Identidade e representação da realidade entre os" rappers" de São Paulo. São Paulo, EdUSP.

HALL, S; DU GAY, P. (eds.) (1996). Questions of cultural identity. Londres, Sage.

HARVEY, D. (2014). Cidades rebeldes: do direito à cidade à revolução urbana. São Paulo, Martins Fontes.

HOLSTON, J. (2013). Cidadania insurgente: disjunções da democracia e da modernidade no Brasil. São Paulo, Companhia das Letras.

JOVCHELOVITCH, S.; PRIEGO-HERNANDEZ, J. (2013). Sociabilidades subterrâneas: identidade, cultura e resistência em favelas do Rio de Janeiro. Brasília, Unesco.

KEISHA-KHAN, Y. P. (2004). The roots of black resistance: Race, gender and the struggle for urban land rights in Salvador, Bahia, Brazil. Social Identities, v. 10, n. 6, pp. 811-831.

KOWARICK, L. (1991). Cidade e Cidadania. São Paulo em perspectiva, v. 5, n. 2, pp. 2-8.

LEFEBVRE, H. (2001). O direito à cidade. São Paulo, Centauro.

MARICATO, E. (2017). O impasse da política urbana no Brasil. Petrópolis, Vozes Limitada.

MARSHALL, T. (1967). Cidadania, classe social e status. Rio de Janeiro, Zahar.

MIRAFTAB, F. (2004). Invented and invited spaces of participation: neoliberal citizenship and feminists' expanded notion of politics. Wagadu: Journal of Transnational Women's and Gender Studies. Disponível em: <http://sites.cortland.edu/wagadu/wp-content/uploads/sites/3/2014/02/ miraftab.pdf>. Acesso em: 15 jan 2019.

(2009). Insurgent planning: situating radical planning in the global south. Planning Theory, v. 8, n. 1, pp. 32-50.

(2016). Insurgência, planejamento e a perspectiva de um urbanismo humano. Revista Brasileira de Estudos Urbanos e Regionais, v. 18, n. 3, pp. 363-377.

(2020). Insurgency and Juxtacity in the Age of Urban Divides. Urban Forum, v. 31, n. 3, pp. 433-441.

MEAD, G. H. (1934). Mind, self and society. Chicago, University of Chicago Press.

ONU-HABITAT (2020). World Cities Report 2020. Disponível em: <https://unhabitat.org/sites/default/ files/2020/11/world_cities_report_2020_abridged_version.pdf>. Acesso em: dez 2020.

PATROCÍNIO, P. R. T. (2013). Escritos à margem: a presença de autores de periferia na cena literária brasileira. Rio de Janeiro, Faperj.

PERLMAN, J. E. (1977). O mito da marginalidade: favelas e política no Rio de Janeiro. Rio de Janeiro, Paz e Terra.

ROY, A. (2011). Slumdog cities: Rethinking subaltern urbanism. International Journal of Urban and Regional Research, v. 35, n. 2, pp. 223-238.

SANTOS, C. N. F. (1981). Movimentos urbanos no Rio de Janeiro. Rio de Janeiro, Zahar.

SANTOS, W. (1979). Cidadania e Justiça: a política social na ordem brasileira. Rio de Janeiro, Campus.

SOUSA SANTOS, B. (2002). A crítica da razão indolente: contra o desperdício da experiência. São Paulo, Cortez.

(2019). O fim do império cognitivo: a afirmação das epistemologias do Sul. São Paulo, Autêntica. 
VAINER, C.; BIENENSTEIN, R.; TANAKA, G. et al. (2013). O Plano Popular da Vila Autódromo: uma experiência de planejamento conflitual. In: XV ENANPUR. Anais... Recife.

VALLADARES, L. (2000). A gênese da favela carioca. A produção anterior às ciências sociais. Revista Brasileira de Ciências Sociais, v. 15, n. 44, pp. 5-34.

(2016). A invenção da favela: do mito de origem à favela.com. Rio de Janeiro, editora FGV.

WATSON, V. (2013). Planning and the "stubborn realities" of global south-east cities: Some emerging ideas. Planning Theory, v. 12, n. 1, pp. 81-100.

Received: March 15, 2019

Approved: May 15, 2019 
